\title{
Dynamic equilibrium of sediment carbon content in an estuarine tidal flat: characterization and mechanisms
}

\author{
Takashi Sakamaki $^{1,2, *}$, Osamu Nishimura $^{1}$ \\ ${ }^{1}$ Department of Civil Engineering, Tohoku University, 6-6-06 Aramaki-Aza-Aoba, Sendai 980-8579, Japan \\ ${ }^{2}$ Present address: Department of Forest Sciences, University of British Columbia, 3041-2424 Main Mall, Vancouver, \\ British Columbia V6T 1Z4, Canada
}

\begin{abstract}
In a long-term and a short-term study of 2 estuarine intertidal flats (sandy and muddy), sediment carbon contents were measured every 2 wk over $2.5 \mathrm{yr}$ and daily for a 2 wk period, respectively. During the long-term study, current velocity was measured twice (for periods of 8 wk and 6 wk). During the short-term study, sediment traps were also deployed. In both tidal flats, sediment carbon content fluctuated but had no long-term trend, indicating dynamic equilibrium. Amplitude, period and mechanisms of dynamic equilibrium differed between the 2 tidal flats. In the sand flat, the carbon content of the surficial sediment $(0$ to $1 \mathrm{~cm}$ ) fluctuated, ranging from 0.03 to $0.17 \%$. It is likely that physical transport of particulate carbon (e.g. by deposition) increases sediment carbon content under calm conditions, while carbon is washed out of the sediment through sand resuspension during spring tides. These processes are probably responsible for the dynamic equilibrium in the sand flat. In the mud flat, the carbon content of the surficial sediment varied from 0.5 to $2.4 \%$, showing sharp peaks after summer floods, and gradual increases in winter followed by a decrease in spring to a lower limit of 0.5 to $1.0 \%$. In the mud flat, the consolidated sediment layer probably governs the dynamic equilibrium of sediment carbon content: it prevents a long-term increase in carbon content by withstanding the transport of deposited particulate carbon into the sediment layer and destabilizing it on the sediment surface; it also maintains the lower limit of sediment carbon content by compaction of organic matter. Sediment organic content is crucial for benthos occupation; thus, our results suggest that the dynamics of sediment quality in tidal flats should be taken into account when assessing or managing benthic communities of tidal flats.
\end{abstract}

KEY WORDS: Dynamic equilibrium · Sediment carbon content · Intertidal flat · Permeable sand . Consolidated mud $\cdot$ Deposition $\cdot$ Entrainment $\cdot$ Estuary

Resale or republication not permitted without written consent of the publisher

\section{INTRODUCTION}

Studies in shallow waters have shown cycles of episodic and intensive sedimentation followed by long-term gentle erosion (Eyre \& Twigg 1997, Christie et al. 1999). Geomorphologic studies in intertidal flats have found that short-term (days to weeks) sedimentation or erosion has little long-term influence on bed elevation (Gouleau et al. 2000, Li et al. 2000, O'Brien et al. 2000). These studies suggested that sedimentation and erosion of particulate material occurs sequentially resulting in regular temporal variation in bed elevation, and also that sediment quality may vary and have some pattern to its temporal variation. Some tidal flats with sediments of relatively high organic content have shown seasonality in organic content (Delafontaine et al. 2000, Pasternack \& Brush 2001). However, the characteristics and mechanisms of such temporal variation are still unclear. It is also not known how the long-term organic content level is affected by short-term fluctuations. 
Temporal variation in the organic content of sediment potentially depends on physical transport of organic matter at the sediment-water interface, which is controlled by extrinsic factors such as bed-shear stress and particulate carbon concentration in the overlying water. In addition, the stability of sediment surfaces, an important factor for resuspension, is enhanced by intrinsic factors such as cohesion (e.g. Otsubo \& Muraoka 1986, Torfs et al. 2001) and benthic, microalgal, extracellular metabolites (e.g. Widdows et al. 2000, Van de Koppel et al. 2001, Friend et al. 2003). Biological production and consumption of organic matter also potentially affect the organic content of sediment. However, the relative importance of these factors is unclear.

In intertidal flat ecosystems, sedimentary organic matter is an important descriptor of habitat quality for benthic organisms. Particulate organic matter is a fundamental component of energy flow in ecosystems, but also consumes oxygen and induces hypoxic and anoxic conditions, potentially leading to benthos die-offs (Forbes et al. 1994, Norkko et al. 2002). In sediment, organic matter occurs mainly in the fine fractions. Previous studies have shown that organic and silt contents of sediment affect both spatial and temporal variations in species, density and productivity of macrobenthos (e.g. Peterson \& Rosenberg 1978, Frouin 2000, Ysebaert \& Herman 2002, Thrush et al. 2003). In addition, some experimental field studies have shown that benthic communities on tidal flats are severely damaged by episodic deposition of fine material, and recovery can take at least several months (Norkko et al. 2002, Hewitt et al. 2003, Bolam et al. 2004, Lohrer et al. 2004). Lohrer et al. (2004) showed that an intertidal flat community was damaged by a layer of fine sediment deposit $<3 \mathrm{~mm}$ thick that persisted over $10 \mathrm{~d}$, indicating the high sensitivity of benthos communities. These experimental studies also suggested that fine material and organic content of tidal flat sediments could be a limiting factor for benthos occupation.

Intertidal flat ecosystems are biologically productive and diverse, and also valuable from the perspective of fishery resources. Sustainable conservation of such ecosystems necessitates the prevention of processes that drastically modify sediment quality, which in turn requires elucidation of the processes causing changes in sediment quality. In short, the mechanisms leading to stability in sediment quality need clarification. As mentioned above, sediment carbon content is temporally variable, and drastic changes in sediment organic content damage or modify the macrofauna. Hence, it can be assumed that in stable tidal-flat ecosystems, which can maintain benthic macrofauna throughout the period of their life expectancy (at least a few years), sediment carbon content is maintained within a limited range, resulting in dynamic equilibrium with no negative impact on macrobenthos communities. In such dynamic equilibrium, temporal variation in sediment carbon content is probably governed by some mechanisms that enable it to recover from or withstand excessive changes. This study examined the dynamic equilibrium of sediment carbon content in 2 stable tidal flat ecosystems with different sediment properties - sandy and muddy. We addressed the following: (1) Does dynamic equilibrium of sediment carbon content occur in stable tidal flat ecosystems? (2) What are the amplitude and period of variation in sediment carbon content in such dynamic equilibrium? (3) What are the mechanisms and factors contributing to such dynamic equilibrium?

\section{MATERIALS AND METHODS}

Study site. We studied 2 intertidal flats in Nanakita River Estuary $\left(38^{\circ} 15^{\prime} \mathrm{N}, 141^{\circ} 0^{\prime} \mathrm{E}\right)$ on the east coast of Honshu Island, Japan (Fig. 1). The Nanakita River discharges 10 to $15 \mathrm{~m}^{3} \mathrm{~s}^{-1}$ fresh water (average annual flow) to the Pacific Ocean. This estuary is categorized as a tide-dominated estuary by the classification method of Harris et al. (2002). A sandbar in the mouth of this estuary reduces wave intrusion and tidal flow, and results in calm conditions within the estuary (Tanaka \& Shuto 1989). We studied a sandy intertidal flat on the north bank of the estuary and a muddy intertidal flat on the south bank, each with an area of about 2 ha. On each tidal flat, we established 3 replicate points for sampling and measurement at $15 \mathrm{~m}$ intervals, marking them with wooden stakes. All samples and measurements were taken within a $3 \mathrm{~m}$ radius around each stake. Previous research had shown that each flat contained different macrofauna dominated by 1 specific species: Nuttallia olivacea (bivalve) in the sand flat, Neanthes japonica (polychaete) in the mud flat (Sakamaki 2001).

Long-term sampling. To examine long-term variation in sediment carbon content, we collected a sediment core of $4 \mathrm{~cm}$ diameter and $15 \mathrm{~cm}$ length at each sampling point at low tide, every $2 \mathrm{wk}$, mainly during spring tides, from June 2001 to March 2004. In the laboratory, the core samples were sliced into 0-1, 1-2, 3-4, 6-7, and 9-10 cm sections until June 2002 and thereafter into $0-1,1-2$, and $3-4 \mathrm{~cm}$ sections. The sliced sediment samples were oven-dried $\left(105^{\circ} \mathrm{C}\right.$, $24 \mathrm{~h})$, homogenized with a mortar and pestle, deepfrozen, and then analyzed for total carbon content with a total organic carbon analyzer (Shimadzu TOC-5000A with Solid Sample Module) and for organic content by determining dry weight loss on combustion $\left(600^{\circ} \mathrm{C}\right.$, $2 \mathrm{~h}$ ). In addition, every 2 to $3 \mathrm{mo}$, bed elevation (sur- 


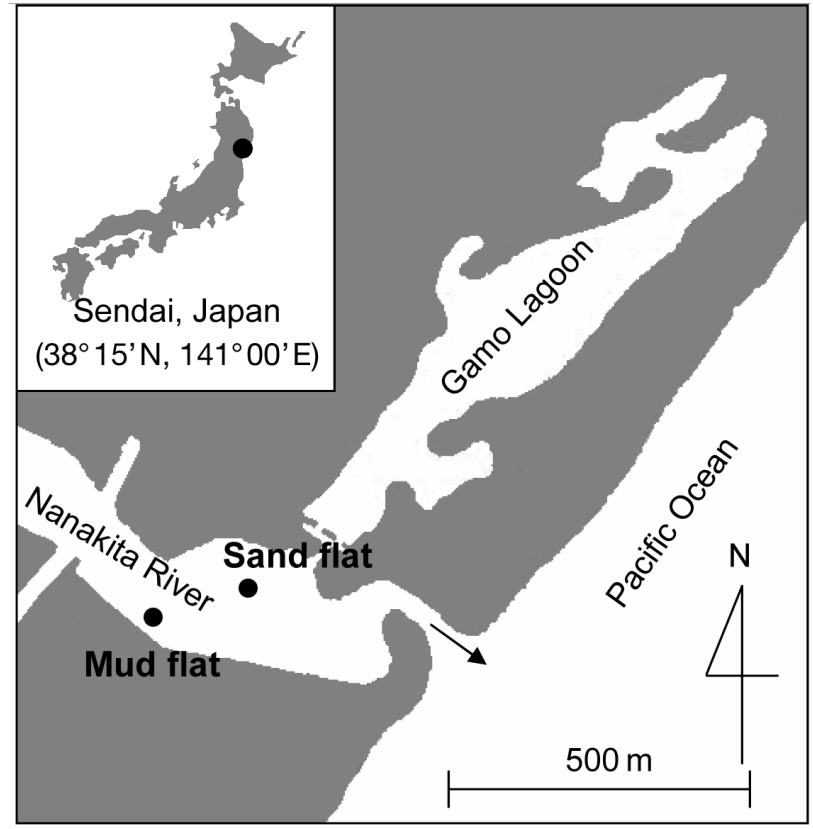

Fig. 1. Intertidal sand and mud flats studied in Nanakita River Estuary, Sendai, Japan. A sampling station (๑) was set up on each tidal flat, each with 3 sampling points set up at $\sim 15 \mathrm{~m}$ intervals

veyed by transit and staff), sediment grain-size distribution of the 0 to $2 \mathrm{~cm}$ layer, and the abundance and wet weight of macrobenthos were measured at all sediment sampling points. Macrobenthos were collected by sifting sediment from a column of $16 \mathrm{~cm}$ diameter and $30 \mathrm{~cm}$ depth through a $1 \mathrm{~mm}$ sieve.

Short-term sampling. We also conducted a $2 \mathrm{wk}$ (August 5 to 19, 2003) series of daily sediment samplings combined with current velocity measurements and sediment-trap sample collections. During this short-term sampling period, a sediment core of $4 \mathrm{~cm}$ diameter was collected daily at each sampling point at low tide; only the 0 to $1 \mathrm{~cm}$ section was analyzed for total carbon, chlorophyll a ( $\mathrm{chl} a)$, phaeophytina (phaeo a) and silt content. Carbon content was determined by the same procedure as for the long-term sampling. Chl a and phaeo a were measured to estimate the amount of living and degrading algal material, respectively. For analysis of chl a and phaeo a content, the subsamples (about $1 \mathrm{~g}$ ) were extracted in methanol (about $10 \mathrm{ml}$ ) for $24 \mathrm{~h}$ in a freezer and then centrifuged. Concentrations of chl $a$ and phaeo $a$ were determined by measuring fluorescence of the extract before and after acidifying with $0.1 \mathrm{~N}$ hydrochloric acid. To determine silt content, sediment samples of known dry weight (a few grams) were placed in $100 \mathrm{ml}$ distilled water in a glass bottle. The bottle was manually well shaken for $30 \mathrm{~s}$ and the water then filtered through a $74 \mu \mathrm{m}$ sieve, and filtered through a GF/C fil- ter; silt weight was determined as the difference in the dry weight of the filter before and after filtration.

During short-term sampling, to examine the quantity and quality of material physically exchanging at the sediment-water interface, a polyethylene sedimenttrap bottle $(5 \mathrm{~cm}$ aperture, $9 \mathrm{~cm}$ external diameter, $16 \mathrm{~cm}$ height) was filled with distilled water and set up each day at low tide on the sediment surface at each sampling point. The bottles were collected the following day. In the laboratory, the slurry of material deposited in the sediment-trap bottles was well mixed and subsamples were collected for chl a and phaeo $a$ measurement. The remainder of the sample was ovendried and subsamples were taken to measure carbon and silt content $(<74 \mu \mathrm{m})$. Carbon, chl $a$ and phaeo $a$ contents were determined as described above. In addition, the total dry weight of the deposited material (total solid) was measured, including the subsample weights. Daily gross deposition flux of particulate carbon and total solid were then estimated for each sampling interval between the daily sediment and trap samplings.

The mean dry bulk densities of the surface layer sediment for the sand and mud flats during the long-term sampling were 1.56 and $1.15 \mathrm{~g} \mathrm{~cm}^{-3}$, respectively. These values were used to estimate potential variation in sediment carbon content from carbon fluxes of physical and biological processes.

Current velocity and water level. To determine the thresholds of hydrodynamic conditions that give rise to substantial variation in sediment carbon content and the timescales at which they occur, we measured current velocities $5 \mathrm{~cm}$ above the sediment surface at both tidal flats from August to September 2003 (8 wk) and from January to February 2004 (6 wk). This included the sampling period of the short-term sediment and sediment-trap study in August 2003. These data were collected in $30 \mathrm{~s}$ bursts $(1 \mathrm{~Hz})$ at $10 \mathrm{~min}$ intervals by electromagnetic, horizontal 2-dimensional currentvelocity meters (Alec Electronics, compact-EM).

The water level was concurrently measured at 10 min intervals (Rigo, RMD-5) at the mud flat. Temporal variation in the water depth at each sampling point was estimated by subtracting the bed elevation from the water level.

Analysis of relationship of current velocity with sediment carbon content and carbon deposition. Critical hydrodynamic conditions initiating the substantial changes in sediment carbon content and gross deposition flux were determined from the results of the short-term sampling and current velocity measurements. To do this, we examined the relationship of sediment carbon content each day with the daily distributions of current velocities during the $1 \mathrm{~d}$ interval immediately preceding sediment sampling. Likewise, 
we examined the relationship of each daily gross carbon deposition flux with the daily distribution of current velocities during sediment-trap sampling.

First, for each daily sediment-sampling interval during the short-term sampling period, we calculated $F(V>v)$, i.e. the frequency $F$ with which the observed current velocity $V$ exceeded a given level, $v(1 \leq v \leq$ $30 \mathrm{~cm} \mathrm{~s}^{-1}$ at $1 \mathrm{~cm} \mathrm{~s}^{-1}$ intervals). Second, the relationships between sediment carbon content $(\mathrm{n}=13)$ and $F(V>v)(\mathrm{n}=13$ for each $v)$, and between gross carbondeposition flux $(\mathrm{n}=13)$ and $F(V>V)(\mathrm{n}=13$ for each $v)$ were analyzed by linear regression for $F(V>v)$ at every $v$ level $(1 \leq v \leq 30)$. Finally, we compared the coefficients of determination $\left(\mathrm{r}^{2}\right)$ among different $v$ values to determine the critical hydrodynamic conditions initiating substantial changes in sediment carbon content and gross deposition flux.

\section{RESULTS}

\section{Sediment characteristics}

The sediment in the mud flat had higher silt, organic and carbon contents than that in the sand flat (Table 1). The mud flat sediment was consolidated, while the sand flat sediment was unconsolidated and permeable. During the long-term measurements, bed elevation, median grain size, silt content, organic content and total carbon content fluctuated but showed no distinct longterm trend. The maximal variation in bed elevation between sampling intervals in the sand and mud flats was 11 and $3 \mathrm{~cm}$, respectively, which were observed immediately after an intense river flood. The correlation between sediment carbon content and sediment organic content was statistically significant on each tidal flat (sand: $\mathrm{r}=0.63, \mathrm{p}<0.0001$; mud: $\mathrm{r}=0.81, \mathrm{p}<0.0001$ ).

\section{Macrobenthos}

There were only a few species in each tidal flat which occurred in every sampling date during the long-term sampling (Table 2). In the sand flat, the bivalve Nuttallia olivacea displayed by far the highest biomass, and Lineidae (nemertines) were present in the highest numbers. The density of Nuttallia olivacea was temporally more stable than that of other species, such as Lineidae and the polychaete Neanthes japonica. In the mud flat, Neanthes japonica was predominant in biomass, while Lineidae were highest in density but temporally unstable. The biomass of $N$. japonica varied seasonally, being high in summer and low in winter, as recorded during previous research in this estuary (Kikuchi 1998).
Table 1. Intertidal sand and mud flats in Nanakita River Estuary. Mean \pm SE of bed elevation $(n=16)$, median grain size $(\mathrm{n}=13)$, silt content $(<74 \mu \mathrm{m}$ fraction) (sand flat $\mathrm{n}=3$; mud flat $\mathrm{n}=13)$, organic content (loss on combustion) $(\mathrm{n}=59)$ and total carbon content $(\mathrm{n}=64)$ during long-term sampling period in sand and mud flats. Values are averages of 3 sampling points on each tidal flat. Bed elevation: difference from annual average water level in this estuary in 2002

\begin{tabular}{|lcc|}
\hline Parameter & Sand & Mud \\
\hline Bed elevation $(\mathrm{cm})$ & $-40.2 \pm 2.2$ & $-53.0 \pm 0.9$ \\
Median grain size $(\mu \mathrm{m})$ & $351 \pm 9.3$ & $230 \pm 17.3$ \\
Silt content $(\%)$ & $0.23 \pm 0.1$ & $23.4 \pm 2.8$ \\
Organic content $(\%)$ & $1.46 \pm 0.03$ & $5.05 \pm 0.13$ \\
Total carbon content $(\%)$ & $0.09 \pm 0.00$ & $0.96 \pm 0.04$ \\
\hline
\end{tabular}

\section{Long-term variation in sediment carbon content}

In the sand flat, the carbon content of the sediment in the surface layer $(0$ to $1 \mathrm{~cm}$ ) fluctuated from 0.03 to $0.17 \%$ during the long-term sampling period and did not show any long-term trend (Fig. 2). In the mud flat, on the other hand, it ranged from 0.51 to $2.4 \%$. Carbon content remained relatively high during winter to spring, with episodic peaks and quick returns to a relatively low background level (0.5 to $1.0 \%$ ) in the other seasons. All the irregular peaks for the mud flat in summer were observed in samples taken a few days after river floods of $>50 \mathrm{~m}^{3} \mathrm{~s}^{-1}$ (discharge monitoring data of Nanakita River from Miyagi Prefecture Government), when unusual and marked deposition of fine, fluid mud was visible in the mud flat. Such peaks, however, were not evident at every river flood. The high carbon content of the mud flat in the winters of 2002 and 2003 may have been attributed to high turbidity of the estuarine water and the high deposition rate associated with a consistent, strong, northwest wind in winter (Sendai District Meteorological Observatory). Autocorrelation coefficients in which 1 sampling interval (about $2 \mathrm{wk}$ ) was considered as a time lag were 0.29 and 0.11 in the sand and mud flats, re-

Table 2. Macrobenthos observed on every sampling occasion during long-term sampling, showing no. $\mathrm{m}^{-2}$ and wet-weight biomass as \% of total biomass. Values are means \pm SE for 11 samplings; coefficient of variation in parentheses. Wet weight of bivalves does not include shell weight

\begin{tabular}{|lcc|}
\hline Species & No. $\mathrm{m}^{-2}$ & Biomass (\%) \\
\hline Sand flat & & \\
$\quad$ Nuttallia olivacea & $971 \pm 110(0.38)$ & $98.6 \pm 0.2$ \\
Lineidae & $986 \pm 229(0.77)$ & $0.6 \pm 0.2$ \\
Neanthes japonica & $330 \pm 89(0.89)$ & $0.5 \pm 0.1$ \\
Mud flat & & \\
$\quad$ Neanthes japonica & $758 \pm 109(0.48)$ & $51.0 \pm 5.1$ \\
Lineidae & $1333 \pm 342(0.85)$ & $37.6 \pm 5.1$ \\
\hline
\end{tabular}




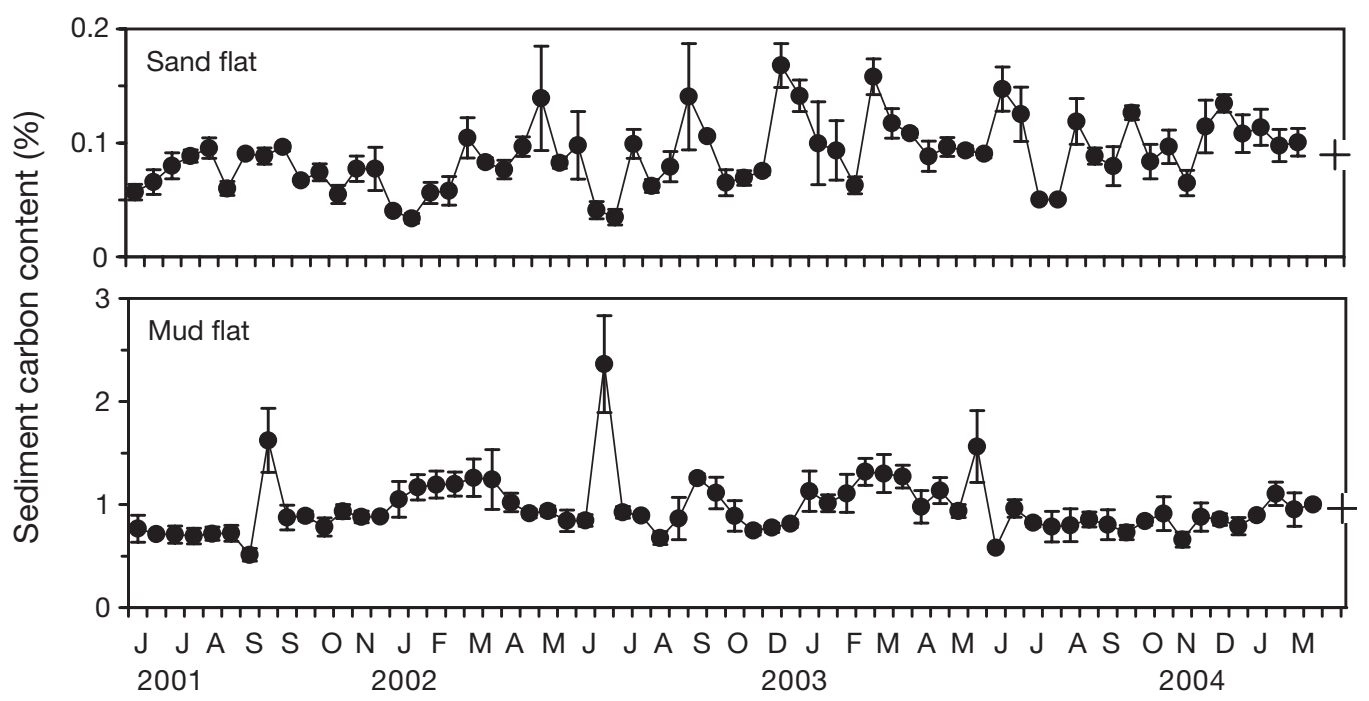

Fig. 2. Temporal variation in sediment carbon content of surface layer (0 to $1 \mathrm{~cm})$ during $2.5 \mathrm{yr}$, long-term sampling period. Data are means \pm SE of 3 sampling points on each tidal flat. Cross on the right-hand ordinates: mean value for the tidal flat during long-term sampling period

spectively, indicating that the sediment carbon content was independent of the previous carbon content level.

In both tidal flats, the carbon content of the surface sediment layer was higher and more variable than that of the deeper layers (Fig. 3). In the sand flat, the sediment carbon content of the 1 to 2 and 3 to $4 \mathrm{~cm}$ layers were synchronized with the carbon content of the surface layer $(0$ to $1 \mathrm{~cm}$ ) as indicated by high coefficients of determination in the regression analyses between the carbon content at the surface layer and in the other layers. In the mud flat, only the carbon content of the 1 to $2 \mathrm{~cm}$ layer was positively associated with that of the 0 to $1 \mathrm{~cm}$ layer.

\section{Daily variation in sediment carbon content and carbon deposition flux}

During the short-term sampling period on the sand flat, the carbon content of the surface layer of sediment and of the material deposited in the sediment traps increased over time, whereas relatively high gross carbon deposition fluxes were more frequently observed in the earlier part of the period (Fig. 4). On the mud flat, the sediment carbon content, gross carbon deposition flux and carbon content of the deposited material fluctuated daily, but there was no trend during the short-term sampling period. The daily variation in sediment carbon content in the sand flat ranged from -0.02 to $0.02 \% \mathrm{~d}^{-1}$ and was much smaller than that in the mud flat, which ranged from -0.34 to $0.39 \% \mathrm{~d}^{-1}$. Autocorrelation coefficients (with $1 \mathrm{~d}$ considered as the time lag) were 0.28 and 0.25 in the sand and mud flats, respectively, indicating that the carbon content level of the sediment was not affected by the level on the previous day.

The gross carbon deposition flux determined from sediment-trap samples was always greater for the sand flat (14 to $155 \mathrm{~g} \mathrm{~m}^{-2} \mathrm{~d}^{-1}$ ) than for the mud flat (8 to $52 \mathrm{~g}$ $\mathrm{m}^{-2} \mathrm{~d}^{-1}$ ). Assuming that all the gross carbon deposited was retained in the 0 to $1 \mathrm{~cm}$ sediment layer, the

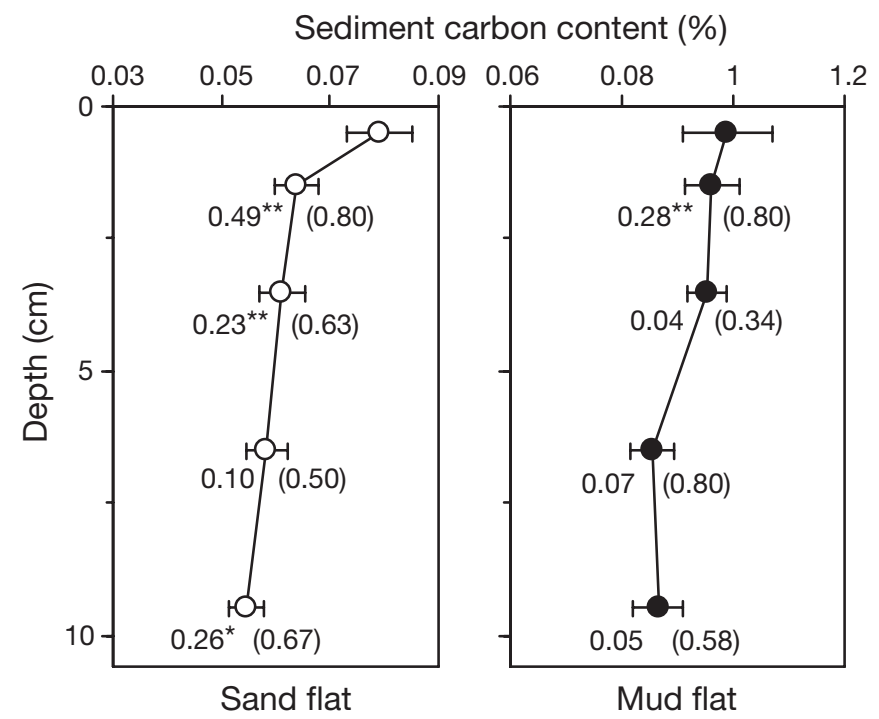

Fig. 3. Vertical profiles of sediment carbon content. Data are means \pm SE from June 2001 to June $2002(n=26)$. Results of simple linear regression analysis for sediment surface layer (0 to $1 \mathrm{~cm}$ ) (explanatory factors) and the other depth layers (dependent factors) are shown next to data points; coefficient of determination: ${ }^{* *} \mathrm{p}<0.0001,{ }^{*} \mathrm{p}<0.05$ (regression coefficients in parentheses) 

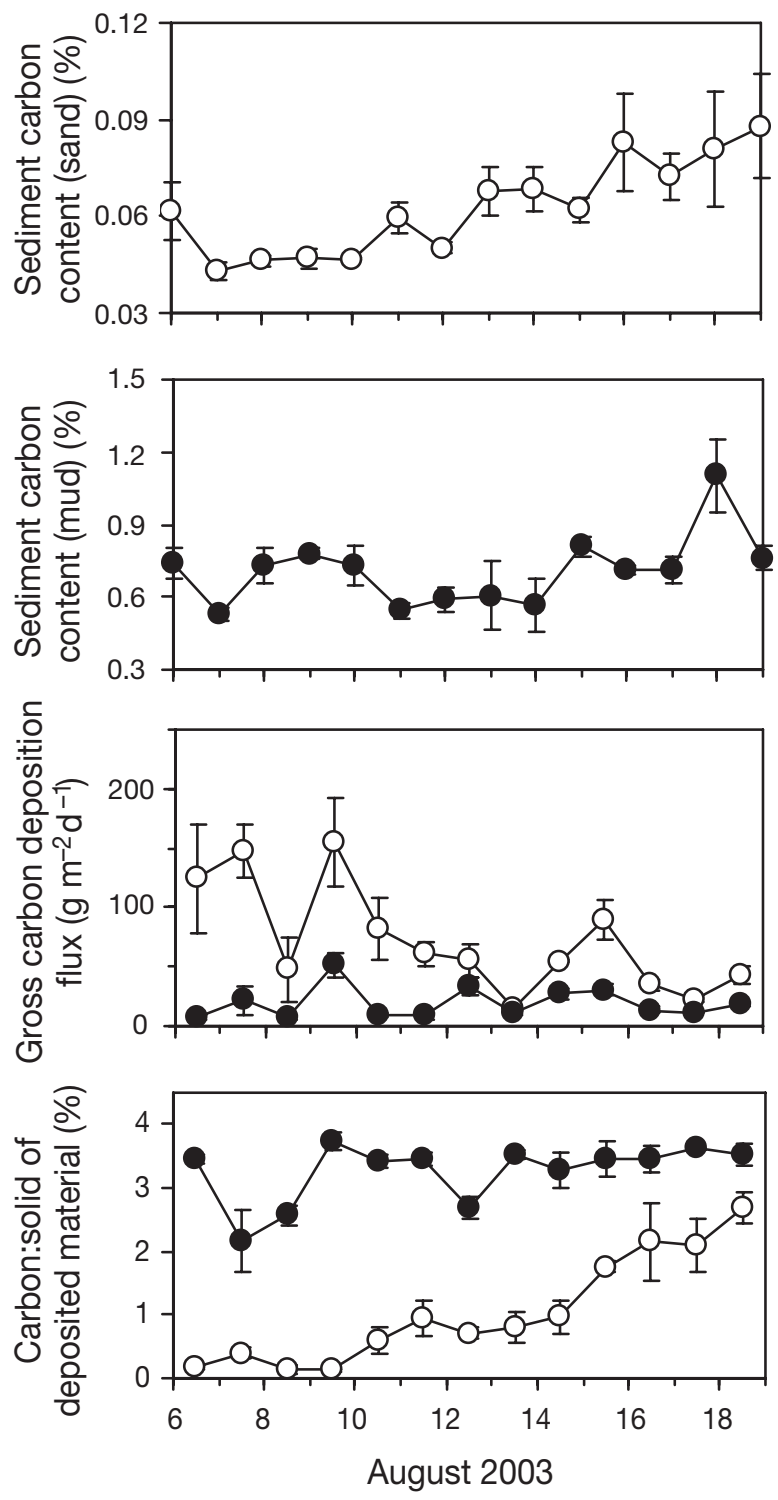

Fig. 4. Daily variation (means $\pm \mathrm{SE}_{;} \mathrm{n}=3$ ) in sediment carbon content of 0 to $1 \mathrm{~cm}$ layer, gross carbon deposition flux and carbon:solid ratio of material deposited in sand and mud flats during short-term sampling period. (0), (0): sand and mud flats, respectively

potential daily increase in sediment carbon content in the surface ( 0 to $1 \mathrm{~cm}$ ) layer was estimated at 0.09 to $0.99 \% \mathrm{~d}^{-1}$ and 0.07 to $0.45 \% \mathrm{~d}^{-1}$ for the sand and mud flats, respectively. These measures of deposition were much greater than the observed increases in sediment carbon content. In particular, in the sand flat, during August 7 to 10, carbon content was constant at about $0.04 \%$ despite great gross deposition. The carbon content of material deposited in the sediment traps was always greater on the mud flat (2.2 to $3.7 \%$ ) than on the sand flat $(0.13$ to $2.7 \%)$. In addition, the carbon content of the deposited material was always greater than that of the sediment on both tidal flats.

During the short-term sampling period, the amount of chl $\mathrm{a}$ in the 0 to $1 \mathrm{~cm}$ layer sediment ranged from 9.7 to 32.0 and 2.6 to $23.5 \mathrm{mg} \mathrm{m}^{-2}$ in the sand and mud flats, respectively. From the maximum $\operatorname{chl} a$ value during the short-term sampling period, the maximum carbon content originating from living algae in the surface layer sediment was estimated at $0.02 \%$ in both sand and mud flats, assuming a carbon:chl a ratio for living algae of 100, which is an intermediate to relatively high value for marine phytoplankton (e.g. Obayashi \& Tanoue 2002). The amount of phaeoa ranged from 1.2 to 24.3 and 31.6 to $58.9 \mathrm{mg} \mathrm{m}^{-2}$ in the sand and mud flats, respectively.

In the sand flat, sediment carbon content was related positively to silt and phaeo a contents and negatively to chl a content (Table 3). In addition, the sediment carbon content was also negatively related to the gross deposition fluxes of total solid and carbon. In the mud flat, sediment carbon content was related positively to silt content only. The carbon content of deposited material had a significant positive relationship to both chl $a$ and phaeo a contents of the deposited material and a significant negative relationship to the deposition flux of total solid in the sand flat. In the mud flat, on the other hand, the carbon content of deposited material was not significantly associated with other parameters. The mean ratio of carbon to phaeo a (C:phaeo a) of the sediment surface layer was distinctly higher than that of the material deposited in the sediment traps. The C:phaeo a of both the surface sediment and the deposited material were higher for the mud flat than for the sand flat.

\section{Relationship of sediment carbon content and deposition flux with hydrodynamic condition}

During the short-term sampling period, current velocity was distinctly higher on the sand flat (8.6, $68.7 \mathrm{~cm} \mathrm{~s}^{-1}$ ) (mean, max.) than on the mud flat (3.7, $35.0 \mathrm{~cm} \mathrm{~s}^{-1}$ ). During this period, sediment carbon content and gross carbon deposition flux showed significant relationships with $F(V>V)$ at particular $V$ values (Fig. 5). In the sand flat, sediment carbon content was negatively and significantly related with $F(V>15)$ (the frequency with which current velocity exceeded $\left.15 \mathrm{~cm} \mathrm{~s}^{-1}\right)\left(\mathrm{r}^{2}=0.57, \mathrm{p}=0.0009\right)$ (Figs. 5 \& 6). Gross carbon deposition for the sand flat showed its most significant positive relationship with $F(V>14)\left(\mathrm{r}^{2}=\right.$ $0.50, \mathrm{p}=0.0018)$, and secondarily with $F(V>5)\left(\mathrm{r}^{2}=\right.$ $0.43, p=0.0222$ ) (Figs. $5 \& 6) . F(V>15)$ was also positively related with gross total solid deposition and negatively with the carbon content of deposited mate- 
Table 3. Results of regression analysis for sand and mud flats between carbon content and silt content $(<74 \mu \mathrm{m})$, chlorophyll $a$ content, phaeophytin a content, gross carbon deposition flux and gross total solid deposition flux, for surface sediment (0 to $1 \mathrm{~cm})$ and material deposited in sediment traps during short-term sampling $(n=13)$. Values are coefficients of determination $\left(r^{2}\right)$. Plus and minus signs indicate positive and negative relationships, respectively. C:phaeo a ratio of surface sediment and deposited material are shown in parentheses. nd: not determined. ${ }^{* * *} \mathrm{p}<0.0001,{ }^{* *} \mathrm{p}<0.01,{ }^{*} \mathrm{p}<0.05$

\begin{tabular}{|c|c|c|c|c|c|}
\hline \multirow[t]{3}{*}{ Dependent } & \multirow{3}{*}{ Silt content } & \multirow{3}{*}{ Chl a content } & \multirow{3}{*}{$\begin{array}{c}\text { Explanatory } \\
\text { Phaeo a content } \\
\text { (C:phaeo a) }\end{array}$} & \multirow{2}{*}{\multicolumn{2}{|c|}{ Deposition flux }} \\
\hline & & & & & \\
\hline & & & & Carbon & Total solic \\
\hline \multicolumn{6}{|c|}{ C content, surface sediment } \\
\hline Sand & $+0.83^{* * *}$ & $-0.49^{* *}$ & $+0.56^{* *}(1207)$ & $-0.37^{*}$ & $-0.36^{*}$ \\
\hline Mud & $+0.49^{* *}$ & -0.04 & $+0.17(2451)$ & +0.01 & +0.005 \\
\hline \multicolumn{6}{|c|}{$\mathrm{C}$ content, deposited material } \\
\hline Sand & nd & $+0.59^{* *}$ & $+0.90^{* * *}(150)$ & -0.30 & $-0.35^{*}$ \\
\hline Mud & nd & +0.03 & $+0.29(382)$ & +0.001 & -0.07 \\
\hline
\end{tabular}

rial (Fig. 6). These results also showed that a threshold of $F(V>15)$ occurred between 0.10 and 0.15 , above which carbon content of both sediment and material deposited in the sediment traps decreased and gross deposition flux of both carbon and total solid increased. For the mud flat, on the other hand, while sediment carbon content was not significantly related with any $F(V>V)$, gross carbon deposition flux showed a significant positive relationship with $F(V>7)\left(\mathrm{r}^{2}=0.46, \mathrm{p}=0.0104\right)$. The daily values of $F(V>15)$ for the sand flat and $F(V>7)$ for the mud flat displayed peaks during the current velocity measurements which roughly corresponded to the spring tides of the 2 wk cycle (Fig. 7). Both $F(V>15)$ for the sand flat and $F(V>7)$ for the mud flat were higher in the winter measurement than in the summer measurement. For the sand flat, most of the periodic peaks of daily $F(V>15)$ reached or exceeded the range of 0.10 to 0.15 which marks the threshold for a drop in sediment carbon content.

There are 2 possible sources for particulate material trapped in the sediment traps: recycled material which was resuspended and redeposited repeatedly at the sediment-water interface, and non-recycled material which was imported from outside the investigation area and deposited from the water column. The positive relationship between gross deposition and $F(V>V)$ is attributable to the more active recycling process connected with stronger currents, and also suggests that recycled material was a major component of the trapped material. The recycled material in the sediment traps was not distinguishable from non-recycled material, and sediment-trap results potentially include some bias in regard to the accuracy of the gross depositional flux determinations, particularly under conditions of strong currents and waves (e.g. Gust et al. 1996). However, the results of the sediment-trap samples, deriving a linear relation-
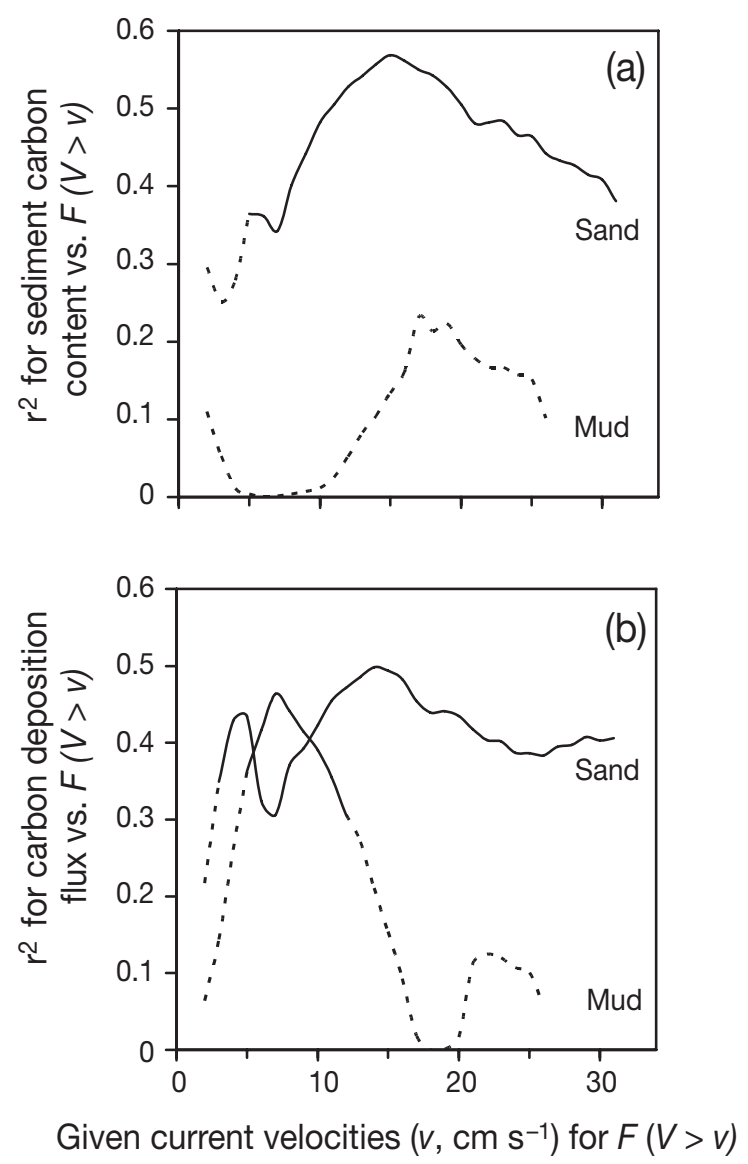

Fig. 5. (a) Relationship between coefficients of determination of sediment carbon content and $F(V>V)$ (i.e. frequency, $F$, with which observed current velocity $V$ exceeds a specific velocity $v$ for $1 \mathrm{~cm} \mathrm{~s}^{-1}$ intervals), and $v$ during short-term sampling. Sediment carbon content and $F(V>v)$ were negatively related. (b) Relationship between coefficients of determination of gross carbon deposition flux and $F(V>V)$, and $v$ during short-term sampling. Gross carbon deposition flux and $F(V>$ $v)$ were positively related. In both graphs, continuous and dotted lines indicate $p<0.05$ and $>0.05$, respectively 

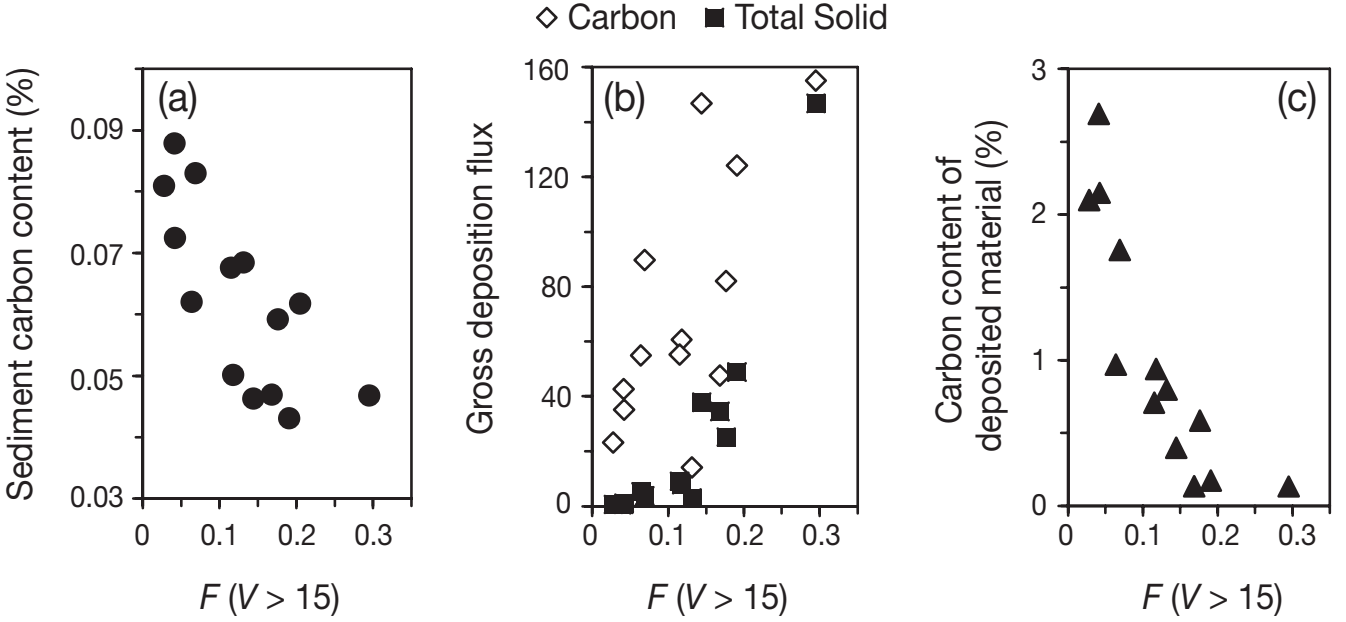

Fig. 6. Relationships between $F(V>15)$, (i.e. frequency $F$ of observed current velocity $V$ exceeding $15 \mathrm{~cm} \mathrm{~s}^{-1}$ ) and (a) sediment carbon content of the $0-1 \mathrm{~cm}$ layer, (b) gross carbon deposition flux $\left(\mathrm{g} \mathrm{m}^{-2} \mathrm{~h}^{-1}\right)$ and total solid deposition flux $\left(\mathrm{kg} \mathrm{m}^{-2} \mathrm{~h}^{-1}\right)$, and (c) carbon content of deposited material, in sand flat during short-term sampling

ship between gross deposition, current and sediment carbon content, was sufficient to track temporal variation in sediment resuspension in our study. Moreover, $F(V>v)$ at the particular $v$ values (i.e. $V=14 \mathrm{~cm} \mathrm{~s}^{-1}$ in the sand flat and $v=7 \mathrm{~cm} \mathrm{~s}^{-1}$ in the mud flat) is thought to be a significant descriptor of sediment resuspension (Fig. 5). Bell et al. (1997) reported that, in combination with tidal currents, even small wind waves initiate sediment transport. Although current and waves were not separable in our current velocity measurements, which detected both together at $1 \mathrm{~Hz}$, we could satisfactorily quantify the threshold $F(V>v)$ for sediment resuspension. Hanes (1991) also reported that intermittent sand resuspension was related to momentary current variation by shoaling waves measured at $1 \mathrm{~Hz}$ with electromagnetic, current-velocity meters.

\section{DISCUSSION}

\section{Dynamic equilibrium of sediment carbon content}

Our long-term sampling results showed that shortterm variation in sediment carbon content has no lasting long-term effects, resulting in a limited range of carbon content variation at each tidal flat. Our results indicate that sediment carbon content is not static but is in dynamic equilibrium at both tidal flats. The fact that the amplitude and period of temporal variation in sediment carbon content in the sand and mud flats were totally different suggests that different mechanisms govern the dynamic equilibrium in the 2 tidal flats.

\section{Mechanisms governing dynamic equilibrium of sediment carbon content}

Processes increasing sediment carbon content

Oxygen flux measurements at our 2 sites showed a maximum net production of 2.9 and $-1.1 \mathrm{mmol} \mathrm{O}_{2} \mathrm{~m}^{-2}$ $\mathrm{h}^{-1}$ in the sand and mud flats, respectively (Sakamaki et al. 2006). The positive net production of the sand flat was equivalent to an increase in sediment carbon content of only $0.002 \% \mathrm{~d}^{-1}$, even assuming daytime production over $10 \mathrm{~h}$ and ignoring nighttime net respiration. Hence, in situ production of benthic microalgae did not substantially contribute to the increase in sediment carbon content in both tidal flats. This was also supported by other results of our study, i.e. the negative relationship between carbon and chl a content in the sand flat sediment, and the small contribution $(<0.02 \%)$ of algal carbon to sediment carbon in comparison with the increase in sediment carbon content in the mud flat (frequently $>0.1 \% \mathrm{~d}^{-1}$ ).

Gravitational deposition of particulate carbon from the water column was probably responsible for the increase in sediment carbon content in both tidal flats. In addition, the vertical profile of sediment carbon content in the sand flat (Fig. 3) suggests advective transport of fine particles into the sand layer, as has been observed in other studies on permeable sediment (McLachlan \& Turner 1994, Rusch \& Huettel 2000, Ehrenhauss et al. 2004). Biodeposition is also a possible pathway of carbon supply to the sediment in the sand flat, since the bivalve Nuttallia olivacea, which is capable of filter-feeding (Sakamaki 2001), was present there in high densities (Table 2). Widdows et al. (2000) 
showed that biodeposition can substantially increase the organic content of sediment. However, our sampling scheme did not allow us to separate the fluxes of physical and biological transport of particulate carbon from the water column. Meanwhile, the tight relationships between carbon, silt and phaeo a contents of the sediment and material deposited in the sediment traps (Table 3) suggests that decomposing algal material in the fine-particle fraction was the major component of particulate organic matter supplied to both tidal flats.

Processes decreasing sediment carbon content

The maximum, net community respiration in summer were determined by Sakamaki et al. (2006) as 7.7 and $5.3 \mathrm{mmol} \mathrm{O}_{2} \mathrm{~m}^{-2} \mathrm{~h}^{-1}$ in the sand and mud flats, respectively. Based on these values, a potential decrease in sediment carbon content by respiration was estimated at 0.014 and $0.013 \% \mathrm{~d}^{-1}$ in the sand and mud flats, respectively, assuming that community respiration consumed organic carbon only in the surface layer $(0$ to $1 \mathrm{~cm})$ of the sediment and that maximum net respiration continued throughout the day. In the sand flat, the fact that the potential increase in sediment carbon content derived from the gross deposition $\left(<0.99 \% \mathrm{~d}^{-1}\right)$ was usually much greater than observed increases $\left(<0.02 \% \mathrm{~d}^{-1}\right)$ suggests some process or processes removing large amount of carbon from the sediment in both tidal flats to maintain the level of sediment carbon. However, the respiration estimated for the sand flat $\left(0.014 \% \mathrm{~d}^{-1}\right)$ was unlikely to contribute to maintaining the relatively low level of sediment carbon. Also, in the mud flat, it was evident
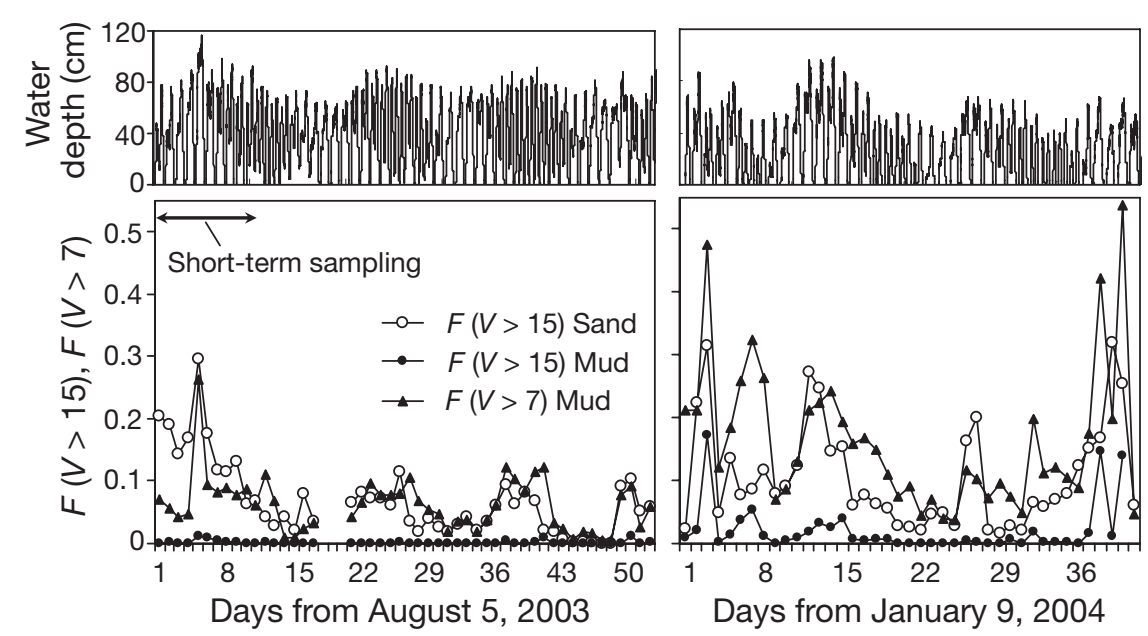

Fig. 7. Temporal variation in daily $F(V>15)$ in sand flat, and $F(V>15)$ and $F(V>7)$ in mud flat during current velocity measurements in summer 2003 and winter 2004. Upper graphs: water depth at mud flat. Arrow indicates short-term sampling period that respiration $\left(0.013 \% \mathrm{~d}^{-1}\right)$ could not account for the observed decrease in sediment carbon $\left(<0.34 \% \mathrm{~d}^{-1}\right)$ (Fig. 4).

In the sand flat, the concomitant decreases in the carbon content of the sediment and that of material deposited in the sediment traps under high $F(V>15)$ (Fig. 6) indicates that the decrease in sediment carbon was associated with sand resuspension. In the mud flat, although sediment carbon content was not clearly related to sediment resuspension, the sediment-trap measurements showed extensive sediment resuspension that could potentially cause a substantial decrease in sediment carbon (Fig. 4). Therefore, sediment resuspension was probably the dominant factor responsible for the decrease in sediment carbon in both tidal flats.

\section{Carbon entrainment in sand flat}

In the sand flat, as particulate carbon is mingled with the permeable sediment, sand resuspension is indispensable to entrainment of particulate carbon. When sediment is resuspended, fine material deposits more slowly than coarser sand because of its small grain size and low specific gravity; thus, it is more readily exported out of the sand flat. This process may selectively remove particulate carbon from the sediment. The lowest value for sediment carbon in the sand flat $(0.04 \%)$ in our study may be the lower limit attainable by this process. The fact that $F(V>5)$ was related to gross carbon deposition flux but not to sediment carbon content (Fig. 5) indicates that carbon resuspension linked to $F(V>5)$ has less influence on sediment carbon content than that linked to $F(V>15) . F(V>5)$ may represent the entrainment of particulate carbon on the sediment surface that was not mingled with the sand layer and comprised a minor fraction of the sediment carbon content of the permeable sandy sediment.

The $2 \mathrm{wk}$ period of the $F(V>15)$ peaks (Fig. 7) suggests that increased sediment carbon content was offset fairly concurrently by the spring tides in the sand flat. Since sediment carbon content tended to increase in relatively calm conditions (Figs. 4 \& 7), probably through particulate carbon transport from the water column, this offset process may have been fundamental to maintaining a state of dynamic equilibrium and keeping the sediment carbon content relatively low. In addition, previous research has shown that fine material deposited in interstitial spaces 
between sand grains consolidates sediment over time (e.g. Torfs et al. 2001). Hence, the periodic entrainment of fine material from the sediment may also prevent cohesion of sand particles, thus maintaining the physical sediment properties of the sand flat.

\section{Carbon entrainment in mud flat}

The stratiform structure of fluid mud and consolidated sediment layers are well known (Nichols 1984, Ross \& Metha 1989). Fine material cannot conceivably shift into a less permeable, consolidated, sediment layer by advection, and thus surficial fine material is physically unstable. Unstable fine material on the sediment surface is easily resuspended because of the low threshold of shear stress for entrainment (e.g. Kusuda et al. 1984). This physical instability of material deposited on the sediment surface is believed to enable the quick return of sediment carbon content from high to background levels (e.g. immediately following episodic river floods, and in spring). Since neither gross carbon deposition flux nor $F(V>7)$ were significant descriptors of daily variation in sediment carbon content, the daily timescale of our mud flat measurements was probably not short enough to reveal the dynamics of unstable fluid mud at the sediment-water interface, and to determine their relationship with the daily variation in sediment carbon levels. To explain daily variations in the carbon content of the sediment surface layer in the mud flat, temporal variations in deposition flux and shear stress should be considered on a timescale shorter than $1 \mathrm{~d}$.

The lower phaeo a content of the mud flat compared to the sand flat (Table 3) indicates that the organic matter of its sediment was relatively degraded and aged. In addition, other results (T. Sakamaki unpubl. data) showed the ratio of carbon to nitrogen $(\mathrm{C}: \mathrm{N})$ to be lower in the sand flat $(7.6 \pm 2.4$, mean $\pm \mathrm{SD})$ than in the mud flat $(13.4 \pm 1.9)$, supporting the presence of aged organic matter in the mud flat sediment. Since consolidated sediments generally have a higher threshold of shear stress for resuspension than unconsolidated sediments (e.g. Otsubo \& Muraoka 1986), particulate carbon in the consolidated sediment layer is not easily flushed out. This probably accounts for the lower limit of carbon content of sediment surface layer in the mud flat (about $0.5 \%$ ).

In the mud flat, the consolidated sediment layer has 2 important functions in withstanding or preventing strong variation in its carbon content: (1) It prevents long-term increases in carbon levels by withstanding the transport of deposits of fine material into the sediment layer and destabilizing fine material on the sediment surface; (2) it controls the lower limit of sediment carbon content by physical compaction of organic matter. The ordinary dynamics of material at the sediment-water interface in the mud flat probably do not contribute to forming the consolidated sediment with high carbon content, because there was no sign of freshly incorporated organic material in the sediment layer (e.g. high C:phaeo a, high C:N). The consolidated sediment layer may have been formed by a less frequent event such as an intense river flood. However, mechanism and timescale responsible for forming the consolidated sediment are still unclear.

\section{Implication for benthos occupation}

The organic content of sediment can be a limiting factor for benthos occupation. Our results for macrobenthos showed that each tidal flat in this study is an appropriate habitat for a particular species; the sand flat is dominated by Nuttallia olivacea and the mud flat by Neanthes japonica. Each macrobenthos species is believed to have a range of sediment organic content suitable for its continued occupation. Yajima \& Kurihara (1981) showed that Nuttallia olivacea prefers sediment with a relatively low carbon content and Neanthes japonica prefers sediment with a high carbon content. In addition, previous experimental research has shown that additional deposition of fine material can severely affect benthos occupation, particularly in sand flats (e.g. Norkko et al. 2002, Hewitt et al. 2003, Lohrer et al. 2004). However, in each of the two tidal flats studied, a state of dynamic equilibrium stabilized sediment quality and maintained the organic content level within a range suitable for benthos occupation.

\section{CONCLUSION}

In this study, the dynamic equilibrium of sediment carbon content has been demonstrated and characterized for a sand and a mud flat. In both flats, particulate carbon transport at the sediment-water interface, such as deposition and resuspension, is probably more responsible for dynamic equilibrium than biological processes, such as mineralization and primary production. In the sand flat, flushing of particulate carbon from the permeable sediment is the key process enabling dynamic equilibrium, whereas in the mud flat, the cohesive sediment layer is probably the key factor. However, in the mud flat, our study was unable to determine a significant descriptor for the daily temporal variation in sediment carbon content or the mechanism and timescale of formation of the cohesive sediment layer; thus clarification requires further study. For conservation of intertidal flat ecosystems, 
sustainable benthos occupation may become a key objective. Our results suggest that dynamic equilibrium of sediment organic content is one essential criterion for successful and sustainable occupation by benthos.

Acknowledgements. We thank A. Kato for sediment analysis. Thanks also to Y. Ogawa and other members of the Environmental Ecological Engineering Laboratory, Department of Civil Engineering, Tohoku University, for assistance with sampling and fieldwork. We thank H. Tanaka for comments on data analysis. We especially thank J. S. Richardson for comments on this manuscript. This research was funded by Grants-in-Aid for Research and Development of Construction Technology, the Japanese Ministry of Land, Infrastructure and Transport.

\section{LITERATURE CITED}

Bell RG, Hume TM, Dolphin TJ, Green MO, Walters RA (1997) Characterisation of physical environmental factors on an intertidal sandflat, Manukau Harbour, New Zealand. J Exp Mar Biol Ecol 216:11-31

Bolam SG, Whomersley P, Schratzberger M (2004) Macrofaunal recolonization on intertidal mudflats: effect of sediment organic and sand content. J Exp Mar Biol Ecol 306: $157-180$

Christie MC, Dyer KR, Turner P (1999) Sediment flux and bed level measurements form a macro tidal mudflat. Estuar Coast Shelf Sci 49:667-688

Delafontaine MT, Flemming BW, Bartholom A (2000) Mass balancing the seasonal turnover of POC in mud and sand on a back-barrier tidal flat (southern North Sea). In: Flemming BW, Delafontaine MT, Liebezeit G (eds) Muddy coast dynamics and resource management. Elsevier Science, Amsterdam, p 107-124

Ehrenhauss S, Witte U, Bühring SI, Huettel M (2004) Effect of advective pore water transport on distribution and degradation of diatoms in permeable North Sea sediments. Mar Ecol Prog Ser 271:99-111

Eyre B, Twigg C (1997) Nutrient behaviour during post-flood recovery of the Richmond River Estuary northern NSW, Australia. Estuar Coast Shelf Sci 44:311-326

Forbes TL, Forbes VE, Depledge MH (1994) Individual physiological responses to environmental hypoxia and organic enrichment: implication for early soft-bottom community succession. J Mar Res 52:1081-1100

Friend PL, Ciavola P, Cappucci S, Santos R (2003) Bio-dependent bed parameters as a proxy tool for sediment stability in mixed habitat intertidal areas. Cont Shelf Res 23: 1899-1917

Frouin P (2000) Effects of anthropogenic disturbances of tropical soft-bottom benthic communities. Mar Ecol Prog Ser 194:39-53

Gouleau D, Jouanneau JM, Weber O, Sauriau PG (2000) Short- and long-term sedimentation on MontportailBrouage intertidal mudflat, Marennes-Oléron Bay (France). Cont Shelf Res 20:1513-1530

Gust G, Bowles W, Giordano S, Hüttel M (1996) Particle accumulation in a cylindrical sediment trap under laminar and turbulent steady flow: an experimental approach. Aquat Sci 58:297-326

Hanes DM (1991) The intermittent suspension of sand due to shoaling waves. In: Soulsby R, Bettess R (eds) Sand trans- portation in rivers, estuaries and the sea. Balkema, Rotterdam, p 125-129

Harris PT, Heap AD, Bryce SM, Porter-Smith R, Ryan DA, Heggie DT (2002) Classification of Australian clastic coastal depositional environments based upon a quantititative analysis of wave, tide, and river power. J Sediment Res 72:858-870

Hewitt JE, Cummings VJ, Ellis JI, Funnell G, Norkko A, Talley TS, Trush SF (2003) The role of waves in the colonization of terrestrial sediments deposited in the marine environment. J Exp Mar Biol Ecol 290:19-47

Kikuchi E (1998) Life history and dispersal pattern of the polychaete worm Neanthes japonica (Izuka) in the Nanakita River Estuary, Miyagi Prefecture. Jpn J Limnol 59: $125-146$

Kusuda T, Umita T, Koga K, Futawatari T, Awaya Y (1984) Erosional process of cohesive sediments. Water Sci Technol 17:891-901

Li C, Wang P, Daidu F, Bing D, Tiesong L (2000) Open-coast intertidal deposits and the preservation potential of individual laminae: a case study from east-central China. Sedimentology 47:1039-1051

Lohrer AM, Thrush SF, Hewitt JE, Berkenbusch K, Ahrens M, Cummings VJ (2004) Terrestrially derived sediment: response of marine macrobenthic communities to thin terrigenous deposits. Mar Ecol Prog Ser 273:121-138

McLachlan A, Turner I (1994) The interstitial environment of sandy beaches. PSZN I: Mar Ecol 15:177-211

Nichols MM (1984) Effects of fine sediment resuspension in estuaries. In: Mehta AJ (eds), Estuarine cohesive sediment dynamics. Proceedings of a workshop on cohesive sediment dynamics. Springer-Verlag, Berlin, p 5-42

Norkko A, Thrush SF, Hewitt JE, Cummings VJ and 5 others (2002) Smothering of estuarine sandflats by terrigenous clay: the role of wind-wave disturbance and bioturbation in site-dependent macrofaunal recovery. Mar Ecol Prog Ser 234:23-42

Obayashi Y, Tanoue E (2002) Growth and mortality rates of phytoplankton in the northwestern North Pacific estimated by the dilution method and HPLC pigment analysis. J Exp Mar Biol Ecol 280:33-52

O'Brien DJ, Whitehouse RJS, Cramp A (2000) The cyclic development of a macrotidal mudflat on varying timescales. Cont Shelf Res 20:1593-1619

Otsubo K, Muraoka K (1986) Resuspension of cohesive sediments by currents. In: Wang SY, Shen HW, Ding LZ (eds) River sedimentation, Vol 3, Proceedings of the third international symposium on river sedimentation. China Ocean Press, Beijing, p 1680-1689

Pasternack GB, Brush GS (2001) Seasonal variation in sedimentation and organic content in five plant associations on a Chesapeake Bay tidal freshwater delta. Estuar Coast Shelf Sci 53:93-106

Peterson TH, Rosenberg R (1978) Macrobenthic succession in relation to organic enrichment and pollution of the marine environment. Oceanogr Mar Biol Annu Rev 16:229-311

Ross MA, Mehta AJ (1989) On the mechanics of lutoclines and fluid mud. J Coast Res 5:51-62

Rusch A, Huettel M (2000) Advective particle transport into permeable sediments - evidence from experiments in an intertidal sandflat. Limnol Oceanogr 45:525-533

Sakamaki T (2001) Analysis of organic matter dynamics forming tidal flat ecosystems. PhD dissertation, Tohoku University, Japan (in Japanese)

Sakamaki T, Nishimura O, Sudo R (2006) Tidal time-scale variation in nutrient flux across the sediment-water interface of an estuarine tidal flat. Estuar Coast Shelf Sci 67:653-663 
Tanaka H, Shuto N (1989) Field measurement of topography at a river mouth. In: Wang SY (eds) Proceedings of international symposium on sediment transport modeling. American Society of Civil Engineers, New York, p 480-485

Thrush SF, Hewitt JE, Norkko A, Nicholls PE, Funnell GA, Ellis JI (2003) Habitat change in estuaries: predicting broad-scale responses of intertidal macrofauna to sediment mud content. Mar Ecol Prog Ser 263:101-112

Torfs H, Jiang J, Mehta AJ (2001) Assessment of the erodability of fine/coarse sediment mixture. In: McAnally WH, Mehta AJ (eds) Coastal and estuarine fine sediment processes. Elsevier Science, Amsterdam, p 109-123

Van de Koppel J, Herman PMJ, Thoolen P, Heip CHR (2001)

Editorial responsibility: Howard Browman (Associate Editorin-Chief), Storebø, Norway
Do alternate stable states occur in natural ecosystems? Evidence from a tidal flat. Ecology 82:3449-3461

Widdows J, Brinsley MD, Salkeld PN, Lucas CH (2000) Influence of biota on spatial and temporal variation in sediment erodability and material flux on a tidal flat (Westerschelde, The Netherlands). Mar Ecol Prog Ser 194:23-37

Yajima T, Kurihara Y (1981) Analysis of the factors controlling establishment and distribution of benthic and sessile organisms in the intertidal flat. Jpn J Ecol 31:107-116 (in Japanese with English abstract)

Ysebaert T, Herman PMJ (2002) Spatial and temporal variation in benthic macrofauna and relationships with environmental variables in an estuarine, intertidal soft-sediment environment. Mar Ecol Prog Ser 244:105-124

Submitted: January 11, 2006; Accepted: April 17, 2006 Proofs received from author(s): November 28, 2006 